\title{
"The growth strategies of a global pharmaceutical company: a case study of Aspen Pharmacare Holdings Limited"
}

\begin{tabular}{|c|c|c|}
\hline AUTHORS & \multicolumn{2}{|l|}{$\begin{array}{l}\text { Victoria Margaret Hodgon } \\
\text { Muhammad Ehsanul Hoque }\end{array}$} \\
\hline ARTICLE INFO & \multicolumn{2}{|c|}{$\begin{array}{l}\text { Victoria Margaret Hodgon and Muhammad Ehsanul Hoque (2017). The growth } \\
\text { strategies of a global pharmaceutical company: a case study of Aspen } \\
\text { Pharmacare Holdings Limited. Problems and Perspectives in Management, 15(1- } \\
\text { 1), 248-259. doi:10.21511/ppm.15(1-1).2017.12 }\end{array}$} \\
\hline DOI & \multicolumn{2}{|c|}{ http://dx.doi.org/10.21511/ppm.15(1-1).2017.12 } \\
\hline RELEASED ON & \multicolumn{2}{|l|}{ Thursday, 11 May 2017} \\
\hline RECEIVED ON & \multicolumn{2}{|l|}{ Monday, 24 October 2016} \\
\hline ACCEPTED ON & \multicolumn{2}{|l|}{ Friday, 06 January 2017} \\
\hline & \multicolumn{2}{|l|}{$(\mathrm{cc}) \overline{\text { EY-NC }}$} \\
\hline LICENSE & \multicolumn{2}{|c|}{$\begin{array}{l}\text { This work is licensed under a Creative Commons Attribution-NonCommercial } 4.0 \\
\text { International License }\end{array}$} \\
\hline JOURNAL & \multicolumn{2}{|c|}{ "Problems and Perspectives in Management" } \\
\hline ISSN PRINT & \multicolumn{2}{|l|}{$1727-7051$} \\
\hline ISSN ONLINE & \multicolumn{2}{|l|}{$1810-5467$} \\
\hline PUBLISHER & \multicolumn{2}{|c|}{ LLC "Consulting Publishing Company "Business Perspectives" } \\
\hline FOUNDER & \multicolumn{2}{|c|}{ LLC "Consulting Publishing Company "Business Perspectives" } \\
\hline & & ニニ:- \\
\hline NUMBER OF REFERENCES & NUMBER OF FIGURES & NUMBER OF TABLES \\
\hline 34 & 2 & 2 \\
\hline
\end{tabular}

(c) The author(s) 2023. This publication is an open access article. 
Victoria Margaret Hodgon (South Africa), Muhammad Ehsanul Hoque (South Africa)

\title{
The growth strategies of a global pharmaceutical company: a case study of Aspen Pharmacare Holdings Limited
}

\begin{abstract}
Given the rapid and sustained growth of Aspen over the past decade, the main aim of this study is to identify and analyze the growth strategies, adopted by Aspen over the period from 2004 to 2014. The research method used was a descriptive study through a single case study of Aspen by analyzing secondary data in the form of publicly available company reports and presentations, as well as financial results, issued between 2004 and 2014. The study finds that, guided by strategic and visionary leadership, Aspen adopted a number of growth strategies including (i) organic growth, as a key factor in creating incremental value for Aspen and its stakeholders, (ii) inorganic growth, in the form of carefully planned and well executed acquisitions, aligned to the Group strategy, (iii) extending territorial coverage through global expansion, particularly into emerging pharmaceutical countries, and (iv) ongoing investment in production capabilities as a means of achieving a strategic advantage. Despite the challenges of intense competition, restrictive legislation, pressure on medicine prices, currency volatility and market specific risks, Aspen has delivered doubledigit earnings growth to its shareholders for 16 consecutive years.
\end{abstract}

Keywords: challenges, global expansion, growth strategy, leadership, pharmaceutical company, South Africa.

JEL Classification: G20, G21, G32, I22, M10.

Received on: $24^{\text {th }}$ of October, 2017.

Accepted on: $6^{\text {th }}$ of January, 2017.

\section{Introduction}

Aspen Pharmacare Holdings Limited (“Aspen”) is a global supplier of branded and generic pharmaceutical products, as well as infant nutritional and consumer healthcare products in selected territories (Aspen, 2014). The company was established in a suburban home in Durban, South Africa in 1997. A year later it listed on the South African stock exchange, the JSE Limited ("JSE"), through a reverse listing into Medhold Limited (Aspen, 2014). The following year Aspen acquired South African Druggists, the largest South African-owned pharmaceutical company at the time (Cairns, 2011), for R2.4 billion in a highly leveraged hostile takeover, described as a mouse eating an elephant (Tshabalala, 2014). In its 2014 Integrated Report, the Aspen Group reported that for 16 consecutive years it had delivered sustained double-digit earnings growth to its shareholders, with a compound annual growth rate in revenue, operating profit and normalized headline earnings per share exceeding $40 \%$ for this period (Aspen, 2014).

There are a number of diverse approaches to growing a company, and managers are faced with a number of options to choose from and decisions to make in order to achieve sustainable growth. A carefully formulated growth strategy, appropriate to the company and which takes into account the importance of execution and integration, is thus an essential element of business management.

(c) Victoria Margaret Hodgon, Muhammad Ehsanul Hoque, 2017. Victoria Margaret Hodgon, Graduate School of Business and Leadership, University of KwaZulu-Natal (Westville Campus) Durban, South Africa. Muhammad Ehsanul Hoque, Graduate School of Business and Leadership, University of KwaZulu-Natal (Westville Campus) Durban, South Africa.

This is an Open Access article, distributed under the terms of the Creative Commons Attribution-NonCommercial 4.0 International license, which permits re-use, distribution, and reproduction, provided the materials aren't used for commercial purposes and the original work is properly cited.
The crafting of a strategy is management's plan on how the business will be run and is a commitment to pursue a particular set of actions in order to grow the business (Hough et al., 2011). This involves choosing, what activities it will perform as well as those which it will not perform, deciding whether it will compete on price or efficiency or whether it will create a position based on a unique advantage.

Given the rapid and sustained growth of Aspen over the past decade, the main aim of this study was to identify and analyze the growth strategies adopted by Aspen over the period from 2004 to 2014. The research also aimed to determine, what challenges faced Aspen in implementing the growth strategies.

\section{Literature review}

1.1. The growth strategies of a global pharmaceutical company. 1.1.1. The growth imperative. In business it is said that growth is an imperative not an option, and some authors even go to the extent of saying "your company can either grow or die" (Rich, 1999, p. 27). Growth is key to long term success, as it is a prerequisite for increasing revenue, profits and shareholder value. A business that is growing is a healthy business as it ensures that the business has a future and is an attractive prospect for investors (Strategic Direction, 2006).

A survey of over 1,200 chief executives from many of the world's largest and most complex companies, revealed that growth is an imperative, and a focus in the broader business strategies (KPMG, 2015). In particular, in the top strategic priorities and challenges facing CEOs, growth was a factor in every single one (KPMG, 2015). This emphasis on growth has also permeated the leadership structures of many notable companies, who have introduced a 
new category of senior corporate officer known as the Chief Growth Officer (CGO) (Dalton and Dalton, 2006), whose role is aimed at ensuring that sustained and profitable growth remains at the forefront of a company's strategy (Buss, 2014).

There are a number of diverse approaches to growing a company. Growth through internally focused organic growth, externally focused inorganic growth, or a combination of both, is available to most companies, regardless of their size. Each has its benefits, risks and trade-offs and careful planning and execution is required to ensure that the end result creates value for the company (Kuntz, 2014). A carefully formulated growth strategy, appropriate to the company, and which takes into account the importance of execution and integration, is key to achieving sustainable growth.

In the global pharmaceutical industry, faced with pricing and cost pressures, stringent regulations and shrinking margins in both mature and emerging markets, growth is fundamental to continued survival and profitability (Roland, 2013).

1.1.2. Organic growth. Organic growth is the growth rate achieved by a company due to internal operations, which excludes any growth or profit from takeovers, mergers or acquisitions. Organic growth is achieved, when a company grows from within and is also referred to as core growth, as it represents the true growth from the core of the company (Dalton and Dalton, 2006). Organic growth is said to be a good indicator of how well management has used internal resources to expand profits (Investopedia, 2015).

Mognetti (2002, p. xviii) describes organic growth as a permanent opportunity, which is a "stone's throw" away from where a company is currently positioned. Organic growth is said to offer a less expensive, faster and less risky short-term return on investment than external growth (Mognetti, 2002).

A basic form of organic growth involves selling more of a company's existing products to existing customers (Duckler, 2015), and is also known as market penetration. The focus is on leveraging a company's resources and capabilities to optimize existing customer relationships - two of the ways in which this can be achieved, is through an improvement in marketing effectiveness (such as increasing advertising) or sales productivity (such as increasing the sales force). Whilst not overly innovative, these efforts can lead to broad scale and system wide growth if done correctly (Duckler, 2015).

1.1.3. Vertical integration. Vertical integration is the merging together of two businesses that are at different stages of a value chain, contrasted to horizontal integration, which is the merging of two businesses at the same stage of a value chain or produc- tion (Hindle, 2008). Vertical integration thus refers to a company's ownership of vertically related activities, and it can either be backward, where the company takes ownership and control of an activity behind it, such as the production of its own components or inputs, or it can be forward, where the company takes control of an activity further on in the production process, such as activities undertaken by its distributors (Grant, 2010).

The greater a company's ownership extends over stages of the value chain for its products, the greater the degree of vertical integration (Grant, 2010). In this regard vertical integration may also be full, where the company owns the whole value chain, or partial, where the company uses a combination of its own value chain, as well as others (Grant, 2010). One of the major benefits of backward vertical integration is the control, which it gives a company over its access to the inputs, which it requires - including the cost, quality and deliver of such inputs (Hindle, 2008). The conventional determinant of vertical integration is to compare the efficiency of markets with the efficiency of firms, thus if the cost of transacting through the market at a particular stage of the value chain is greater, than the cost of administering the activity within the company, then vertical integration should take place for the benefit of the company (Grant, 2010).

In the generic pharmaceutical industry there is often a clear demarcation between the upstream and downstream segments of the supply chain. Upstream manufacturers produce active pharmaceutical ingredients (APIs) using raw materials, such as basic and intermediate chemicals, solvents and catalysts. APIs, which are chemical compounds with therapeutic properties, are supplied to downstream manufacturers, who combine the APIs with inactive ingredients and process them into finished dose forms such as tablets (Kubo, 2011).

An important part of generic product development is the sourcing of APIs (Kubo, 2011). As a result, backward vertical integration by a generic drug manufacturer into API manufacturing provides critical, mass and a number of advantages, including greater control of the supply chain, the ability to ensure timely availability of the required API to allow uninterrupted production of the generic products, input cost, reduction resulting in greater profit margins - all of which contribute to the growth of the generic company.

1.1.4. Takeovers, mergers and acquisitions. Takeovers, mergers and acquisitions are forms of inorganic growth, which involve the growth of a company other than from its own business activities. Such inorganic growth is considered to be an accelerated form of growth, as it generally results in new skills and knowledge being available, gives rise to an increase in assets and market share, and provides access to capital 
and new markets faster than by means of organic growth (Kuntz, 2014). Mergers and acquisitions in particular are considered to be key corporate strategy tools, as they are the principal means by which companies can achieve major extensions in the scope of their activities (Grant, 2010).

Whilst takeovers and acquisitions have a similar meaning, an acquisition could relate to either a company or a product. A takeover however generally refers to one company acquiring another company and in so doing taking on the target company's operations, assets and liabilities. A takeover may have a negative connotation particularly in the context of a hostile takeover which is when the the takeover is accomplished without the acquiring company, coming to an agreement with the target company's management, but instead acquiring shares directly from the target company's shareholders in order to gain a controlling interest in the target company (Investopedia, 2015).

A merger is when two companies amalgamate to form a new company, requiring agreement by the shareholders of both companies. Mergers often occur, when the companies involved are of similar size and strength (Grant, 2010).

Whilst mergers and acquisitions ("M\&As") are not new to the global pharmaceutical industry, the current dealmaking activity, which is taking place has been described as "a frenetic explosion of M\&A activity" (Wieczner, 2015) "merger fever" (Megget, 2015) and "a record wave of dealmaking" (Ward, 2015). According to a KPMG report, in the first half of 2015, the total global closed deal value in the pharmaceutical sector was approximately US $\$ 170$ billion, nearly double the total closed deal value for the whole of 2014 (KPMG, 2015).

\subsubsection{Internationalization and the focus on emerg-} ing markets. In the pursuit of growth, new customers and profitability, internationalization presents a multitude of markets and offers vast opportunities to companies. At the same time, such expansion is complex and requires a thorough understanding of how to formulate and implement strategies for competing globally (Grant, 2010).

Moving from a national to an international business environment requires a focus on the profit implications of such expansion. The profitability of entering a foreign market rests upon two key factors: (i) the attractiveness of that market, and (ii) whether the company can establish a competitive advantage within such market, particularly in relation to local companies and other multinationals. This latter requirement depends on the company's ability to transfer or replicate its capabilities and resources to the new location whilst still retaining their effectiveness in conferring competitive advantage (Grant, 2010).
Assuming these two requirements are met, and the company determines that the potential exists for it to create value from internationalization are only the start of the journey. Thereafter, the company needs to design the international strategy as well as the suitable organisational structures and systems to support it (Grant, 2010).

1.1.6. Glocalization. A purely global strategy is on which views the world as a single market (Grant, 2010). Whilst there are certain benefits to having a global strategy, the need for national differentiation should not be overlooked. Glocalization (a combination of the words globalization and localization) is the integration of local elements into global products. It involves balancing the efficiency opportunities of global scale with the need for local adaption, and recognizes that there is a greater likelihood of succeeding in transplanting a product into a new market, if it is catered to the local region (Matusitz, 2010). Companies should standardise product features and company activities, where economies of scale are substantial, and allow for differentiation where national preferences are strongest - thus a careful combination of global standardisation and local adaptation (Grant, 2010).

1.1.7. Pharmerging markets. Whilst the pharmaceutical industry continues to grow in developed markets, due to macroeconomic factors and the impact of evolving healthcare reforms which result in pricing pressures, the level of future growth is uncertain and expected to flatten (IMS Institute for Healthcare Informatics, 2014). Emerging pharmaceutical markets, so called "pharmerging markets", are however expected to grow more strongly than developed markets and are thus considered to offer significant growth opportunities for pharmaceutical companies (McKinsey \& Company, 2012).

It is expected that by 2016, these rapidly growing emerging markets will amount to almost one third of the global pharmaceutical market (approximately double the percentage in 2006), and are therefore seen to play a vital role in sustaining growth in the pharmaceutical industry (PwC, 2013). Some of the key growth drivers include large populations, an increase in wealth and income levels, a growing trend towards healthier lifestyles, as well as increasing government and consumer awareness about the benefits of a good healthcare system (Deloitte, 2014).

Accessing this untapped potential is however not without its difficulties, as pharmaceutical companies, who attempt to establish or increase their presence in these expanding markets, find that they are faced with a number of risks and challenges, including:

- Increasing government intervention through mechanisms, such as price setting and changes in manufacturing requirements. 
- Increased competition, as local and multinational companies enter these markets.

- Geographic size and cultural diversity.

- Underdeveloped healthcare infrastructure and fragmented distribution systems.

- The growth markets differ politically, geographically, religiously, socially and structurally as well as in terms of the treatments they need and their ability and willingness to pay for new medicines. (PwC, 2012)

Given the commercial potential, which these markets hold, both generic and innovators companies are responding to the opportunities which these new, expanding markets hold either on their own or by pursuing mergers, acquisitions or joint ventures. However given the diversity among these regions, there is no "one-size-fits-all" approach, which can be used (PwC, 2013). Commercial success is thus likely to be dependent on a thorough understanding of each market and its intricacies, investment in local research, development and manufacturing as well as tailoring commercial models and approaches to meet the specific needs and characteristics of each market (Deloitte, 2014). This need for localisation thus requires pharmaceutical companies to balance their global competencies with tailored approaches for the local markets (PwC, 2013).

\section{Methodology}

The purpose of this research was to identify and analyze the growth strategies, adopted by Aspen over the past decade. The nature of this research was thus concerned with finding out "what", as opposed to "why". The question being asked is therefore "what has happened" contrasted with "why did something happen" (Yin, 2012). As a result, the research is of a descriptive nature, as opposed to explanatory in nature, and for this reason a descriptive study was selected as the type of research.

The research method used was a descriptive study through a single case study of Aspen by analyzing secondary data in the form of publicly available company reports and presentations, issued between 2004 and 2014. Qualitative data were extracted and analysed to determine the growth strategies used by Aspen, whilst certain quantitative data were used for illustrative purposes.

A case study is considered to be appropriate for use in a descriptive study, when answering a research question such as "what is happening or has happened?" as a case study is able to provide the detailed descriptions or explanations, required to answer a question of this nature (Yin, 2012). This can be contrasted with the experiment (which may be useful, when trying to determine the effectiveness of an initiative), and the survey (which may be used to determine, how often something has happened) (Yin, 2012). For these rea- sons, a descriptive case study was considered to be the appropriate method for identifying and analyzing Aspen's growth strategies over the past decade. For this study, data were obtained by accessing the Aspen company reports and presentations, issued between 2004 and 2014 and made publicly available on the company's website.

The following documents, for the period 2004 to 2014 (both years inclusive), were downloaded and analyzed:

- annual reports;

- issued interim financial results (December of each year), including results of presentations, announcements and booklets;

- issued final financial results (June of each year), including results of presentations, announcements and booklets; and

- presentations (such as investor and site presentations).

The time period of 2004 to 2014 was selected as (i) Aspen has a 30 June financial year end and thus, at the time of the study, the most current data available were in respect of the 2014 financial year; (ii) working back from the 2014 data, an eleven year period in the company's history was considered long enough to provide valuable insight into the company, whilst at the same time being reasonable and manageable in terms of the researcher's resource constraints.

With regard to the qualitative data, narratives and words were extracted from the accessed documents. Selection of the data for this study was guided by identifying the following:

- key words and themes such as "growth" and "strategy", as well as related words and themes;

- details regarding products (such as launches), transactions, acquisitions (products and businesses), divestments (products and businesses), expansion (of capacity and geographically), partnerships and joint ventures, and capital expenditure projects;

- stated strategies;

- initiatives and success factors;

- core competencies;

- strategic objectives and initiatives;

- company milestones.

\section{Results}

Listed on the South African stock exchange (JSE), with its Group headquarters in Durban, South Africa, Aspen has grown from a company with businesses in South Africa, Australia and the United Kingdom, and a market capitalization of approximately R4.8 million in 2004, to a truly global company with businesses on six continents and a market capitalization of R136 billion in 2014 (Aspen, 2014). 
Aspen is now the largest pharmaceutical company listed on the JSE and is one of the top 20 companies listed on this stock exchange. It is ranked among the top five generic pharmaceutical producers globally and has 26 manufacturing facilities at 18 sites on six continents and approximate- ly $10 \quad 000$ employees (Aspen, 2014). Against this background, the growth of Aspen was considered by tracking the developments reported in the Annual Reports between 2004 and 2014. These company milestones are summarized in Table 1.

Table 1. Aspen milestones up to 2014

\begin{tabular}{|c|c|}
\hline 1850 & e commencement of the business in Port Elizabeth, South Africa, which later became Lennon Limited, the originator company to the Aspen Group today \\
\hline 1997 & $\begin{array}{l}\text { Aspen Healthcare (Pty) Limited began trading with Stephen Saad (current Group Chief Executive) and Gus Attridge (current Deputy Group Chief Execu- } \\
\text { tive), as two of the four founding members }\end{array}$ \\
\hline 1998 & Listed on the JSE through reverse listing into Medhold Limited \\
\hline 1999 & Acquired the pharmaceutical business of South African Druggists for R2.4 billion in a hostile take-over \\
\hline 2001 & Aspen Australia commenced trade as a start-up operation \\
\hline 2003 & Entered into a fostering arrangement with GSK for the marketing and distribution of 40 branded products into the South African private sector \\
\hline 2003 & $\begin{array}{l}\text { Aspen Stavudine was launched - Africa's first generic ARV } \\
\text { Aspen became the first generic company globally to be accredited to the PEPFAR Fund (United States President's Emergency Plan for AIDS Relief) } \\
\text { - The US-based Clinton Foundation announced that it had selected Aspen, together with two other multinational companies, for the manufacture of ARVs }\end{array}$ \\
\hline 2004 & Acquired FCC, the only South African manufacturer of APIs \\
\hline 2004 & Acquired Infacare, the infant nutritional brand, from Dutch-based Royal Numico \\
\hline 2004 & Aspen's multi-million Rand Port Elizabeth-based Unit 1 facility became operational \\
\hline 2005 & Aspen's Unit 1 facility in Port Elizabeth became the world's first manufacturing site to receive tentative US FDA approval for the production of certain generic ARVs \\
\hline 2006 & $\begin{array}{l}\text { Secured distribution rights for a number of important ARVs from MSD, Bristol Myers Squibb, Roche and Tibotec as the Group extended its portfolio as the } \\
\text { biggest supplier of ARVs in Africa }\end{array}$ \\
\hline 2007 & Prestige Brands Incorporated entered into an agreement with Aspen for the supply of eye drops from Aspen's sterile facility in Port Elizabeth to the US market \\
\hline 2008 & Entered the Latin American market through an investment with Strides Acrolab Ltd in businesses established in Brazil, Mexico and Venezuela \\
\hline 2008 & Acquired $60 \%$ of the share capital of Shelys with businesses in Kenya, Tanzania and Uganda \\
\hline 2008 & $\begin{array}{l}\text { Aspen Global, was set up to manage the intellectual property and commercial activities of Aspen's international ventures } \\
\text { Aspen Global acquired the intellectual property rights to four GSK-branded products for R2.7 billion, enabling Aspen to distribute these global } \\
\text { brands, namely Eltroxin, Imuran, Lanoxin and Zyloric, to more than } 100 \text { countries }\end{array}$ \\
\hline 2009 & $\begin{array}{l}\text { Concluded a series of strategic transactions with GSK worth R4.6 billion comprising: } \\
\text { the acquisition of the rights to distribute GSK's pharmaceutical products in South Africa, } \\
\text { the formation of The GSK Aspen Healthcare for Africa Collaboration in SSA to market and sell pharmaceuticals in SSA, } \\
\text { the acquisition of eight specialist branded products for worldwide distribution, and } \\
\text { the acquisition of a manufacturing site in Bad Oldesloe, Germany }\end{array}$ \\
\hline 2009 & $\begin{array}{l}\text { Aspen Healthcare FZ LLC, was set up in Dubai to manage and represent the global brands portfolio in the European, Middle Eastern, North African and } \\
\text { Canadian (EMENAC) region }\end{array}$ \\
\hline 2010 & Aspen Asia Company Limited was established \\
\hline 2010 & Took full control of the Latin American businesses acquired in 2008 \\
\hline 2010 & Beta Healthcare commenced with commercial production at its newly built pharm \\
\hline 2010 & Revenue exceeded R10 billion for the first time \\
\hline 2011 & Acquired the pharmaceutical business of Australian-based Sigma Pharmaceuticals Limited, now Aspen Pharma (Pty) Limited, for R5.9 billion \\
\hline 2012 & For the first time in its history, profits from Aspen's International businesses exceeded those generated by the South African business \\
\hline 2012 & Aspen Philippines Inc. began trading \\
\hline 2012 & Acquired a portfolio of established GSK OTC products in selected territories for R2,1 billion \\
\hline 2013 & The International business became the biggest contributor to Group revenue for the first time \\
\hline 2013 & Acquired a portfolio of 25 established prescription-branded products from GSK ("classic brands") with distribution rights in Australia \\
\hline 2013 & $\begin{array}{l}\text { Aspen Australia commenced the distribution of the leading infant nutritional products in that country following the acquisition of the rights to certain intel- } \\
\text { lectual property licences and the related business by the Aspen Group }\end{array}$ \\
\hline 2013 & $\begin{array}{l}\text { Aspen Healthcare Taiwan Ltd was established } \\
\text { - Aspen Pharmacare Nigeria Limited began trading } \\
\text { Aspen Medical Products Malaysia SDN BHD began trading }\end{array}$ \\
\hline 2013 & $\begin{array}{l}\text { Aspen was one of five South African companies named on the Boston Consulting Group's } 2013 \text { list of "100 Global Challengers" companies from emerging } \\
\text { markets that are "growing so quickly overseas that they are reshaping industries and surpassing many traditional multinational companies" } \\
\text { Aspen Pharmacare was ranked 10th in the Sunday Times' Business Times } 2012 \text { Top } 100 \text { South African Companies, while Group Chief Executive } \\
\text { Stephen Saad received the Sunday Times "Business Leader of the Year" award }\end{array}$ \\
\hline 2014 & $\begin{array}{l}\text { - Aspen was one of four South African companies included on the Boston Consulting Group's } 2014 \text { list of "100 Global Challengers" companies from emerging } \\
\text { markets that are "growing so quickly overseas that they are reshaping industries and surpassing many traditional multinational companies" } \\
\text { Aspen was ranked as the } 10 \text { th most innovative company by Forbes' "The Top } 25 \text { Most Innovative Companies in the World 2014" list (Forbes Sep- } \\
\text { tember 2014) } \\
\text { Aspen was ranked 10th in the top } 100 \text { companies over five years category and second in the top } 40 \text { index companies over five years in the } 2013 \\
\text { Sunday Times "Top } 100 \text { Companies Awards" in South Africa }\end{array}$ \\
\hline 14 & $\begin{array}{l}\text { Acquired an API business and a portfolio of branded finish dose form molecules from MSD as well as two branded injectable anticoagulants and a special- } \\
\text { ised sterile production site from GSK }\end{array}$ \\
\hline
\end{tabular}


Table 1 (cont.). Aspen milestones up to 2014

2014 Established a number of additional offices across Europe, the CIS and in Latin America, increasing coverage to more than 50 locations across the world 2014 Intellectual property rights in related infant nutritional businesses in Latin America and South Africa were acquired from Nestlé

2014 Aspen Japan KK was established

Source: compiled using Aspen company documents.

In addition to the company milestones, a useful way of analyzing the nature of the business and the changes thereto, over the period 2004 to 2014 , was by extracting selected acquisitions and divestments, as depicted in the growth themes depicted in Figure 1:

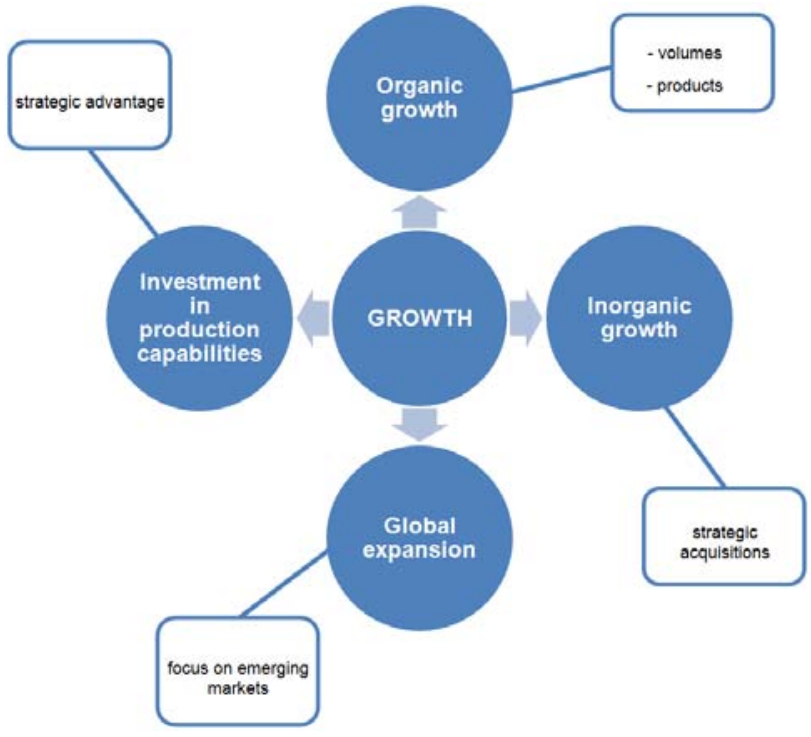

Fig. 1. Aspen growth themes

The growth, achieved by Aspen, is best illustrated in numbers. Table 2 depicts the growth in numbers from 2004 to 2014 in relation to specific indicators.

Table 2. Aspen growth in numbers 2004-2014

\begin{tabular}{|l|c|c|c|c|c|c|c|c|c|c|c|}
\hline & 2004 & 2005 & 2006 & 2007 & 2008 & 2009 & 2010 & 2011 & 2012 & 2013 & 2014 \\
\hline Revenue (R'million) & 2201.7 & 2814.6 & 3449.3 & 4025.9 & 4682.5 & 8441.4 & 9619.2 & 12383.2 & 15255.8 & 19308.0 & 29515.1 \\
\hline Operating profit (R'million) & 553.8 & 738.2 & 894.7 & 1076.6 & 1196.3 & 2174.7 & 2524.4 & 3149.0 & 3940.6 & 5043.3 & 7424.8 \\
\hline $\begin{array}{l}\text { Earnings per share } \\
\text { (cents) }\end{array}$ & 99.8 & 137.6 & 185.3 & 205.6 & 245.3 & 374.6 & 494.9 & 595.5 & 645.8 & 773.0 & 1097.9 \\
\hline $\begin{array}{l}\text { Headline earnings per } \\
\text { share (cents) }\end{array}$ & 103.7 & 138.3 & 185.4 & 210.1 & 231.3 & 389.4 & 482.9 & 520.3 & 650.1 & 788.0 & 1016.3 \\
\hline $\begin{array}{l}\text { Market capitalization at } \\
\text { year-end (R'million) }\end{array}$ & 4788.1 & 9005.3 & 14102.9 & 14413.9 & 12444.7 & 19783.7 & 32845.6 & 36480.8 & 57234.0 & 403 & 136395.8 \\
\hline $\begin{array}{l}\text { Share price at year-end } \\
\text { (cents) }\end{array}$ & 1270 & 2380 & 3650 & 3700 & 3180 & 5475 & 7610 & 8400 & 12585 & 22707 & 29889 \\
\hline $\begin{array}{l}\text { Cash flow from capital } \\
\text { expenditure - property, } \\
\text { plant \& equipment } \\
\text { (R'million) }\end{array}$ & $(158.6)$ & $(81.1)$ & $(174.6)$ & $(287.7)$ & $(379.3)$ & $(626.7)$ & $(632.0)$ & $(651.5)$ & $(469.6)$ & $(667.1)$ & $(1328.9)$ \\
\hline $\begin{array}{l}\text { Cash flow from capital } \\
\text { expenditure - intangible } \\
\text { assets (R'million) }\end{array}$ & $(90.6)$ & $(93.4)$ & $(132.4)$ & $(147.0)$ & $(166.0)$ & $(3279.9)$ & $(660.5)$ & $(188.7)$ & $(2148.8)$ & $(3654.9)$ & $(700.4)$ \\
\hline $\begin{array}{l}\text { Cash flow from acquisition } \\
\text { of subsidiaries and busi- } \\
\text { nesses (R'million) }\end{array}$ & $(50.3)$ & $(262.1)$ & $(267.6)$ & $(0.1)$ & $(1357.5)$ & 102.9 & 33.4 & $(5893.2)$ & $(315.6)$ & $(1578.6)$ & $(19764.2)$ \\
\hline
\end{tabular}

Source: Compiled from Aspen company documents

The impressive growth, shown by Aspen during the period under review, resulted in delivering double-digit earnings growth to its shareholders for 16 consecutive years. This was achieved despite the challenges presented by the industry, as well as the markets, in which Aspen operated at the time. From the comprehensive analysis of the Annual Reports, issued between 2004 and 2014, key words were extracted relating to the challenges faced by Aspen. From these key words, the themes depicted in Figure 2 were identified. 


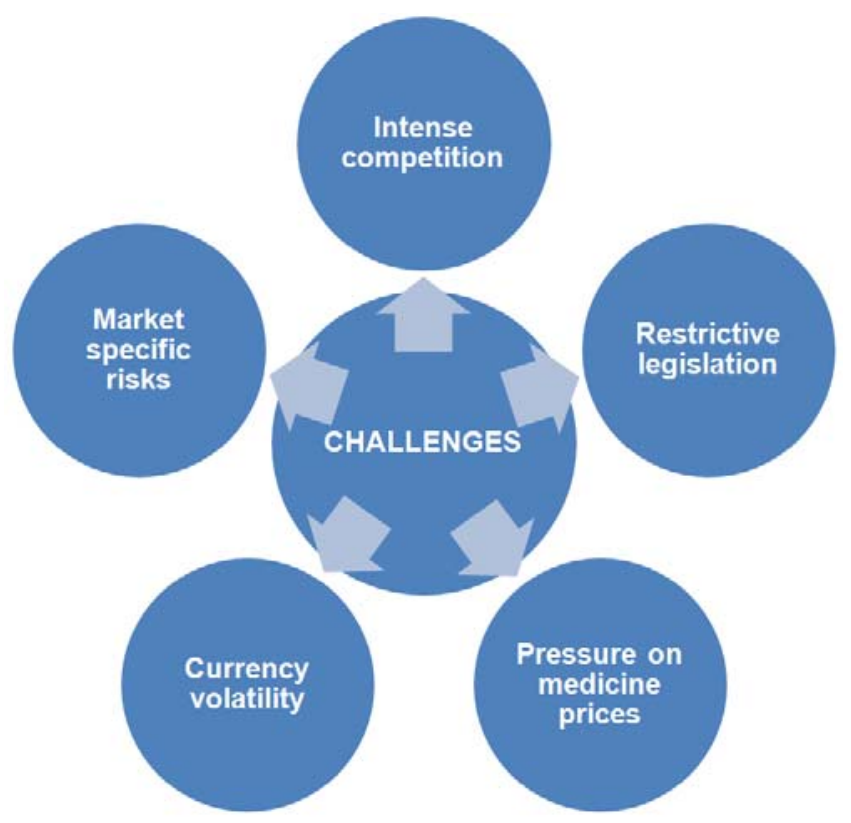

Fig. 2. Aspen "challenge themes"

\section{Discussion}

4.1. Organic growth. “...Aspen recognizes that organic growth provides the most effective return on investment. ...The product pipeline is critical to the future sustainability of the Group, providing opportunities to bring new products to the market and growing Aspen's presence in addition to compensating for any products in decline in the existing portfolio. The product pipeline is a most valuable asset..." (Aspen, 2009, p. 26). Organic growth is achieved, when a company grows from within. Many of Aspen's stated strategic objectives illustrate its recognition of the importance of maintaining organic growth:

- increasing investment in new product development;

- continually commercialising new pharmaceutical products;

- ability to source and launch new product pipeline;

- first to market in new product launches;

- sourcing and launching the new product pipeline; and

- robust product pipeline for targeted strategic regions.

The company therefore placed much focus on developing, and maintaining a strong product pipeline as a form of core growth aimed at selling more products to more customers in order to increase revenues. Aspen also recognized that whilst "(r)evenue growth is an important factor in market share advancement and protection... without an acceptable margin of profit, growth in revenue alone is not a sustainable strategy" (Aspen, 2010, p. 74). As a result, profit generation was a primary objective in the pursuit of growth.
One of the ways, in which profitability was achieved, was through operational strategies which focused on manufacturing capacity and optimising production efficiencies. The effect of this was twofold: (i) with increased volumes, the supply of products was able to meet demand, and (ii) by realizing economies of scale, both the recovery of fixed costs and profit margins were improved.

4.2. Inorganic growth. Aspen did not only focus its efforts on organic growth. Simultaneously it set out to supplement organic growth with strategic product and business acquisitions, with stated strategies including: acquisitive growth; and assessing acquisitive opportunities.

Inorganic growth through acquisitions, effectively allows a company to purchase growth "off-theshelf" (Ward, 2015). Whilst the access to new products and new markets is an attractive prospect for an acquiring company, the literature sets out the drawbacks of such a growth strategy. These include the high cost, particularly in what Megget (2015) describes as the current "M\&A frenzy" of competition for good assets in the pharmaceutical industry. In addition the integration of the acquired product or business often poses a major challenge to the extent that Grant (2010) describes the selection and integration of acquisitions as an organizational capability in itself.

Aspen's approach to acquisitions appears to take all of these factors into account:

- "The acquired businesses and products bring immediate added value to Aspen's earnings potential, as well as providing the infrastructure to allow a continuation of growth into the next decade" (Aspen, 2008, p. 21); 
- "The absence of material acquisitions over the past year has been a consequence of unrealistic pricing, preventing the conclusion of deals which represent value rather than a lack of ambition in this regard" (Aspen, 2007, p. 15);

- Effective integration of acquisitions into the Group and adoption of Aspen's corporate culture is recognized as a key strategic risk which requires focused mitigation activities (Aspen, 2012).

One of the key factors in Aspen identifying and assessing acquisitive opportunities was the need for them to be aligned with its business strategy. As a result, Aspen's product and business acquisitions may be described as strategic, and a closer inspection reveals the strategic intent behind them:

- recognising the benefits of vertical integration, which allows for greater control over the quality and cost of supply of raw materials, Aspen made a number of key acquisitions in pursuit of this strategy. These included:

- the acquisition of FCC (50\% in 2004 and the remaining 50\% in 2009) as a supplier of key APIs; and

- a number of strategic acquisitions in 2014 positioning Aspen as a leading global player in anticoagulants (these included the acquisition of products, a specialized production site, which manufactures certain of these brands, as well as a manufacturing business which supplies the raw material for certain of the brands acquired thereby creating the opportunity to harness benefits from vertical integration).

- Niche and specialized products: Aspen made a number of acquisitions in the pursuit of differentiation from competitors and the access to profitable niche markets with high barriers to entry. These included:

- the building of specialist knowledge and capabilities in the infant nutritional business (2004 acquired the Infacare brand and manufacturing facility in South Africa, 2013 acquired the license rights in Australia and certain southern African territories (including South Africa) from Nestlé, and 2014 acquired license rights and a production facility in Latin America from Nestlé);

- the acquisition of certain products in niche areas of highly specialized treatments from GSK in 2008;

- the acquisition of eight specialist branded products for worldwide distribution from GSK in 2009; and

- the 2014 anticoagulant acquisitions mentioned above related to products with few or no competitor products.

4.3. Global expansion. The literature recognizes that internationalization offers vast opportunities to companies in the pursuit of growth (Grant, 2010). Aspen shared this view as indicated in its stated internationalisation strategy:
- expansion into new markets;

- transforming the organization for international growth; and

- expanding into new markets, with a particular emphasis on emerging markets.

In addition to the creation of business growth opportunities, Aspen diversified its business into international markets in order to mitigate the risk of exposure to a single market. Through its geographic diversification, Aspen decreased its reliance on its domestic South African market, thereby spreading market risk and increasing the scope for robust and sustainable financial growth.

From being a predominantly South African business in 2008, Aspen transformed into a diversified global business by 2012, when profits from Aspen's International businesses exceeded those, generated by the South African business for the first time.

The approach followed was a combination of acquisitive and organic growth in respect of both territory and product expansion. This commenced in 2008 with investments in businesses in Latin America (Brazil, Mexico and Venezuela) and East Africa (Kenya, Tanzania and Uganda), as well as various product acquisitions, which opened up numerous new global markets. Strategically, entities were established as hubs to manage the commercial activities of the international ventures (in Mauritius) and relevant regions, such as EMENAC (in Dubai). Entities were also established in Hong Kong in the year 2010, Philippines in the year 2012, Taiwan in the year 2013, Malaysia in the year 2013 and Japan in the year 2014 as part of the establishment of a footprint in the Asia Pacific region.

The 2014 infant nutritional acquisition from Aspen brought about expansion in Latin America (such as Colombia, Chile, Ecuador and Peru), whilst the 2014 anticoagulant transactions gave rise to expansion in Europe with business units, being set up across Europe, including Eastern Europe and Russia.

Once it had established a leading position in the South African pharmaceutical industry, Aspen continued to diversify its geographic presence to territories outside South Africa. As a result, the Group's global expansion was anchored by the two large, mature concerns in South Africa and Australia, each with a leading market position and an ability to efficiently convert profits into cash. Today South Africa remains the foundation of the business with its Group headquarters situated there.

- Emerging markets: Emerging pharmaceutical markets, so called "pharmerging markets", are considered to offer significant growth opportunities for pharmaceutical companies (McKinsey \& Company, 2012). Aspen recognised this and, in increasing its global footprint, concentrated on emerging markets where robust growth was anticipated. 
Aspen's willingness to deal with the challenging trading conditions and barriers to entry, which were generally present in these pharmerging markets was largely based on the fact that the characteristics of the selected markets had much in common with South Africa (such as a growing population, increasing numbers of the aged, expanding middle class which is susceptible to lifestyle diseases and have heightened awareness of brands, price and quality) (Aspen, 2009).

4.4. Investment in production capabilities. One of Aspen's stated strategic objectives are "to achieve a strategic advantage through our production capabilities" (Aspen, 2014). This is evident from the fact that, in addition to the investment in businesses and products, Aspen pursued profit and growth through the continual expansion and improvement of its production facilities and methods. From 2004 to 2008 approximately R1 billion was spent on property, plant and equipment. A $65 \%$ increase in expenditure from 2008 to 2009 marked the start of three years of investment exceeding R6 million per annum. In 2014 expenditure peaked at R1.3 billion, resulting in the total investment over the 10 year period from 2004 to 2014 being approximately R5.5 billion. The continual investment in property, plant and equipment was aimed at increasing capacity, diversifying and increasing capabilities, as well as expanding into specialised areas of manufacture. This investment in manufacturing capability was intended to provide the Group with the capacity to pursue its growth objectives (Aspen, 2007).

Developing these manufacturing capabilities into a core strength had a number of positive repercussions for Aspen:

- created a catalyst for international expansion;

- transformed Aspen from a domestic producer to a manufacturer with the capability to supply various products to any market in the world;

- became an important supplier to the Group's international business;

- positioned the Group as a quality manufacturer of the highest international standards, providing an access point for the Group's engagement with several of the world's leading pharmaceutical corporations from which additional business collaborations developed;

- maintained gross margins despite the general downward pressure on selling prices; and

- facilitated the critical mass offered by high volume manufacture, resulting in reduced cost of goods and profit improvement. (Aspen company documents)

Through Aspen's ongoing investment in its production capacity and capabilities, it developed its manufacturing into a core competence, which created a competitive advantage and resulted in above average organiza- tional performance, allowing Aspen to pursue growth through increased profitability and expansion.

4.5. The strategy behind the growth. The growth achieved by Aspen between 2004 and 2014 is indicative of a high performance organization. Such growth, attained through organic and inorganic means as well as global expansion and the development of manufacturing as a critical business asset, did not occur by chance. It would therefore be remiss not to mention strategy, which underpinned such growth.the effective formation and implementation of strategy which underpinned such growth.

A number of the theories underlying the concept of strategy can be identified in Aspen's development, such as:

- investing in strategically valuable resources (physical assets, intangible assets or capabilities) to obtain a competitive edge over rivals (Collins and Montgomery, 2008);

- reacting opportunistically to emerging possibilities (Ovans, 2015);

- deliberately choosing a distinctive set of activities to deliver a unique mix of value (Porter, 1996); and

- selecting a strategic position by identifying which activities are incompatible and purposefully limiting what the company offers (Porter, 1996) (here note the divestments referred to in Table 3, Section 3, which illustrate the trade-off decisions made by Aspen);

The literature on strategy suggests that leadership is at the core of strategy (Edinger, 2013), and that the challenge of developing a clear strategy is dependent on leadership (Porter, 1996). Such strategic leadership was demonstrated by Aspen's top management team which:

- recognized the importance of maintaining organic growth as a key factor in creating incremental value;

- identified strategic acquisitive opportunities to supplement organic growth, particularly those which could differentiate Aspen from its competitors and which were a "strategic fit" for the business;

- identified an internationalisation strategy, with a particular focus on emerging markets, as a means of mitigating the risk of exposure to a single market and creating business growth opportunities; and

- built its manufacturing capabilities into a core competence through continuous investment and development, thereby creating a competitive advantage.

Many of the growth strategies adopted by Aspen were in keeping with the trends identified in the studies on the pharmaceutical industry. Whilst As- 
pen's approach was thus not unique, as the largest pharmaceutical company on the South African stock exchange, the JSE, it managed to outgrow and outperform its South African pharmaceutical competitors which, it could be argued, were competing in the same marketplace and had the same growth strategies available to them.

Whilst the growth strategies were thus not unique to Aspen, what the theory and case study results perhaps do not capture is the less concrete concepts underlying such growth. Innovative, passionate, logical, dedicated and persevering are all words, which could be used to describe the characteristics of the skilled and experienced leadership and management, which crafted and executed Aspen's strategy across multiple territories and in so doing guided Aspen along its growth path. The balance of entrepreneurialism and sound business fundamentals is at least one factor which set Aspen apart from its South African competitors.

4.6. Intense competition as challenge. One of the major challenges faced by Aspen was competition. Whilst competition is neither unique to the pharmaceutical industry, nor to South African companies, the generic pharmaceutical industry, as well as the global pharmaceutical industry in general, are characterized by intense competition. In particular, the number of generic companies competing with the launch of a product upon patent expiry of a molecule, as well as the presence of low-cost Asian pharmaceutical businesses in all major territories increases the level of competition in the generic pharmaceutical market space.

4.7. Restrictive legislation as challenge. As the pharmaceutical industry is characterized by a complex and evolving regulatory landscape, legislation posed another challenge to Aspen. Regulatory control aimed at protecting consumers' health and safety, takes the form of quality regulations, which requires a pharmaceutical company to submit its products for registration with the relevant regulatory authority. Such submission must include proof of feasibility of a product, proof of manufacturing capability for product supply and validated product efficacy (Aspen, 2010). This process can take many years, affecting when the product can be launched in the intended market.

As products must be registered in every market in which they are sold, Aspen initially faced challenges only in respect of the South African Medicines Control Council and encountered major delays in the registration of its products, at times with more than 200 products awaiting registration. Following global expansion, Aspen had to deal with the challenge of registering its products in many countries with multiple regulatory agencies each with their own registration requirements.
4.8. Control of medicine prices in $\mathrm{SA}$ as challenge. Another form of regulatory control is aimed at containing the costs of medicines through price regulations. This links to another challenge, which Aspen faced, namely the pressure on medicine prices. In South Africa and most other countries worldwide, regulators seek to reduce the cost of pharmaceuticals through pricing legislation (ref). Working within mandated price increases or price cuts, coupled with rising input costs presented an ongoing challenge to Aspen, requiring initiatives to improve cost competitiveness and protect profit margins.

4.9. Currency volatility. Currency volatility was another challenge faced by Aspen. Prior to its global expansion, Aspen was chiefly concerned with the strength of the Rand relative to other currencies insofar, as it impacted on import and export costs. However, increasing its geographic representation and conducting business in multiple currencies meant that Aspen also had to deal with an increase in currency exposure which could have an influence on its operations and potentially a major influence on its profitability.

Entering into a number of transactions for the acquisition of foreign businesses and assets with an obligation to make payments in foreign currency meant that Aspen was exposed to the risk of exchange rate fluctuations. In addition, having foreign subsidiaries meant that Aspen was exposed to the effect of currency fluctuations particularly in respect of the consolidation of financial statements.

Whilst Aspen's company management could estimate the exposure of the above types of currency exposure, another challenge was presented by unexpected currency fluctuations. As budgets and forecasts are prepared based on certain assumptions about exchange rate movements, unexpected currency rate changes pose a serious risk, as they are not provided for and can therefore substantially impact a company's cash flows and market value.

4.10. Market specific risks. One of the major challenges which Aspen had to deal with as it expanded into new territories was market specific risks. Dealing with the regulatory, cultural and political challenges in different markets, required an in-depth understanding of the nature of each territory in order to determine how to overcome the hurdles presented, and ensure that the business model could succeed in such environment.

Examples of some of the market specific risks faced by Aspen are set out below:

- Developed markets: weak growth mainly as a result of increased pricing regulation, pressure on the growth of these economies;

- Emerging markets: generally challenging trading conditions and barriers to entry; 
- Asia: diverse economic, social, cultural, legal and political environments of the different Asian countries;

- Australia: aggressive legislated price cuts, increased competition and resulting stagnant market;

- Brazil: unpredictable and lengthy product registration timelines;

- Europe: pricing pressures and high cost of labor;

- Latin America: complex market in terms of the operating and regulatory environment specific to each territory (multiple individual markets), barriers to entry, and cultural challenges;

- MENA: individually regulated countries, each at varying levels of healthcare development stages, challenging to navigate, political unrest in some countries;

- South Africa: regulated price increases, weakening currency, inflationary pressures, energy costs, long product registration timelines;

- SSA: political instability, lack of infrastructure, complex regulatory requirements, as well as inconsistency in registration requirements between the regulatory bodies in the various countries, unstable economic climate, differing legis- lation, commercial and cultural circumstances from country to country, easy penetration of counterfeit products to certain markets; and

- Venezuela: challenging economic and political environment, devaluation of the currency.

\section{Conclusion}

Through an analysis of the growth strategies, adopted by Aspen between 2004 and 2014, the study found that, guided by strategic and visionary leadership, the growth strategies were adopted by Aspen during the period were organic growth, being a key factor in creating incremental value for Aspen and its stakeholders; inorganic growth, through carefully planned and well executed acquisitions aligned to the Group strategy; extending territorial coverage through global expansion, with a focus on emerging pharmaceutical markets; and ongoing investment in production capabilities as a means of achieving a strategic advantage. The challenges were intense competition; restrictive legislation; pressure on medicine prices; currency volatility; and market specific risks.

\section{References}

1. Aspen (2014). Aspen Pharmacare Holdings Limited Integrated Report 2014. [Online]. Retrieved from http://www.aspenpharma.com/investor-information/financial-years-data/. (Accessed: 11 October 2015).

2. Aspen (2012). Aspen Pharmacare Holdings Limited Annual Report 2012 [Online]. Retrieved from http://www.financialresults.co.za/2012/aspen_ar2012/annual-report/downloads/Aspen\%20AR_2012_LoRes.pdf. (Accessed: 26 October 2015).

3. Aspen (2010). Aspen Pharmacare Holdings Limited Annual Report 2010 [Online]. Retrieved from http://www.aspenpharma.com/investor-information/financial-years-data/(Accessed: 26 October 2015).

4. Aspen (2009). Aspen Pharmacare Holdings Limited Annual Report 2009 [Online]. Retrieved from http://www.aspenpharma.com/investor-information/financial-years-data/. (Accessed: 26 October 2015).

5. Aspen (2007). Aspen Pharmacare Holdings Limited Annual Report 2007 [Online]. Retrieved from http://www.aspenpharma.com/wp-content/uploads/Reports/aspen_ar_2007/downloads/aspen_ar2007.pdf (Accessed: 26 October 2015).

6. Buss, D. (2014). 'Chief Growth Officer' Title Catches On as a Way to Battle Growth Challenges, Chief Executive, 15 August [Online]. Retrieved from http://chiefexecutive.net/chief-growth-officer-title-catches-way-battle-growthchallenges/ (Accessed: 12 October 2015).

7. Cairns, P. (2011). The Investment Case - Aspen Pharmacare Holdings Ltd, Moneyweb, 12 January [Online]. Available at: http://www.moneyweb.co.za/archive/the-investment-case-aspen-pharmacare-holdings-ltd/. (Accessed: 11 October 2015).

8. Dalton, D.R. and Dalton, C.M. (2006). Corporate growth: Our advice for directors is to buy "organic", Journal of Business Strategy, 27 (2), 5-7.

9. Deloitte. (2014) 2015 Global life sciences outlook: Adapting in an era of transformation [Online]. Available at: https://www2.deloitte.com/content/dam/Deloitte/global/Documents/Life-Sciences-Health-Care/gx-lshc-2015-lifesciences-report.pdf. (Accessed: 26 September 2015).

10. Duckler, M. (2015). Driving Organic Growth [Online]. Available at: http://www.fullsurge.com/perspectives/articles/innovation/driving-organic-growth. (Accessed: 12 October 2015).

11. Edinger, S. (2013). How Strategic Are You? Forbes, 23 October [Online].Available at: http://www.forbes.com/sites/scottedinger/2013/10/23/how-strategic-are-you/. (Accessed: 4 October 2015).

12. Grant, R.M. (2010) Contemporary strategy analysis, $7^{\text {th }}$ ed. United Kingdom: John Wiley \& Sons Ltd.

13. Hindle, T. (2008). The Economist - Guide to Management Ideas and Gurus. London: Profile Books Ltd.

14. Hough, J., Thompson Jr, A.A., Strickland III, A.J. and Gamble, J.E. (2011) Crafting and Executing Strategy, $2^{\text {nd }}$ ed. Berkshire: McGraw-Hill Education.

15. IMS Institute for Healthcare Informatics (2014). Global Outlook for Medicines Through 2018, [Online]. Available at: http://static.correofarmaceutico.com/docs/2014/12/01/informe_ims.pdf. (Accessed: 11 October 2015).

16. Investopedia, LLC (2015) Annual Report [Online]. Retrieved from http://www.investopedia.com/terms/a/annualreport.asp?optm=sa_v1. (Accessed: 22 October 2015). 
17. KPMG (2015). Pharmaceutical and Life Sciences Deals Insights Quarterly Q4 2014 [Online]. Available at: http://pwchealth.com/cgi-local/hregister.cgi/reg/pwc-pharma-deals-insight-q4-2014.pdf. (Accessed: 13 October 2015).

18. Kubo, K. (2011). Explaining Vertical Integration in the Generic Pharmaceutical Industry, Discussion Paper 11-02, January, Indian Statistical Institute, Delhi Planning Unit [Online]. Available at: http://www.isid.ac.in/ pu/dispapers/dp11-02.pdf. (Accessed: 13 October 2015).

19. Kuntz, B.G. (2014). Organic vs. Inorganic: Which Way To Grow? Forbes, 14 January [Online]. Available at: http://www.forbes.com/sites/ey/2014/01/14/organic-vs-inorganic-which-way-to-grow/. (Accessed: 13 October 2015).

20. Matusitz, J. (2010). Disneyland Paris: a case analysis demonstrating how glocalization works, Journal of Strategic Marketing, 18 (3), 223-237.

21. McKinsey \& Company (2012) Unlocking pharma growth: Navigating the intricacies of emerging markets [Online]. Retrieved from http://www.mckinsey.com/ /media/mckinsey/dotcom/client_service/pharma\%20and $\% 20$ medical\%20products/ pmp\%20new/pdfs/emerging_markets_compendium_2012.ashx. (Accessed: 23 August 2015).

22. Megget, K. (2015). Merger fever sweeps pharma, Chemistry World, 10 September [Online]. Available at: http://www.rsc.org/chemistryworld/2015/09/merger-fever-sweeps-pharma. (Accessed: 13 October 2015).

23. Mognetti, J. (2002). Organic Growth: Cost-Effective Business Expansion from Within. England: John Wiley \& Sons Ltd.

24. Ovans, A. (2015). What Is Strategy, Again? Harvard Business Review, 12 May [Online]. Retrieved from https://hbr.org/2015/05/what-is-strategy-again. (Accessed: 27 September 2015).

25. Porter, M. E. (1996). What is strategy? Harvard Business Review, November - December, 61 - 78.

26. PwC. (2012). From vision to decision: Pharma 2020 [Online]. Retriewed from http://www.pwc.com/gx/en/industries/pharmaceuticals-life-sciences/pharma-2020/vision-to-decision.html. (Accessed: 26 September 2015).

27. PwC. (2013). Pharma emerging markets 2.0: How emerging markets are driving the transformation of the pharmaceutical industry [Online]. Retrieved from http://www.strategyand.pwc.com/global/home/what-we-think/reportswhite-papers/article-display/pharma-emerging-markets. (Accessed: 26 September 2015).

28. Rich, J.T. (1999). The Growth Imperative, Journal of Business Strategy, 20(2), pp. 27 - 31.

29. Roland, B. (2013). Global pharmaceutical industry is in a strategic crisis - Business models must be adjusted, 6 January [Online]. Retrieved from http://www.rolandberger.com/press_releases/Pharmaceutical_industry _in_a_strategic_crisis.html. (Accessed: 12 October 2015).

30. Strategic Direction. (2006). Making the most of growth opportunities: Strategies for success, Strategic Direction, 22(8), 26-29.

31. Tshabalala, T. (2014). How a Mouse Ate an Elephant, Forbes Africa, May 2014, 12 - 18.

32. Ward, A. (2015) No end in sight to wave of pharma dealmaking, Financial Times, 26 April [Online]. Available at: http://www.ft.com/intl/cms/s/0/6aad8ebe-e9c0-11e4-b863-00144feab7de.html\#axzz3oLkKuPml. (Accessed: 13 October 2015).

33. Wieczner, J. (2015). The real reasons for the pharma merger boom, Fortune, 28 July [Online]. Available at: http://fortune.com/2015/07/28/why-pharma-mergers-are-booming/. (Accessed: 13 October 2015).

34. Yin, R.K. (2012) Applications of Case Study Research, $3^{\text {rd }}$ ed. Thousand Oaks, California: Sage Publications, Inc. 